\title{
PERCEPTION AND ATTITUDES OF CITIZENS TOWARDS THE ISSUE OF POVERTY IN THE MICROREGION OF KARVINÁ
}

\author{
[Vnímání a postoje občanů k problematice chudoby v karvinském \\ mikroregionu] \\ Ivona Buryová ${ }^{1}$

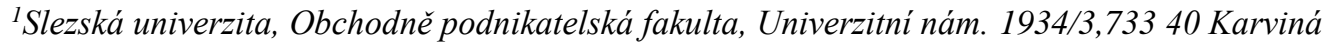 \\ Email:buryova@opf.slu.cz.
}

\begin{abstract}
The theme of the paper is contemporary perception and attitudes of citizens towards the issue of poverty in the micro-region Karvina. The theoretical part describes the current issue of poverty within the European Union with the specification to the Czech Republic. Primarily it is a presentation of the current causes that can lead to poverty in European society. Further space is also devoted to preventive tools of the poverty in the Czech Republic. The content of the second part of the paper is research that has been realized and evaluated in 2017. The aim of the research is the perception and classification an own living standard of the citizens of the Karvina micro-region and the attitudes of citizens towards socially demographic groups that are at risk of poverty and social exclusion. The results of the research are interesting in that they do not always confirmed the theoretical conclusions and hypotheses. In conclusion of the paper are summarized the most important findings from the theoretical and research part.
\end{abstract}

Keywords: living standard, poverty, research, social exclusion, social policy.

JEL classification: A14, D91

Received: 18.10.2018; Reviewed: 26.10.2018; 2.11.2018; Accepted: 6.3.2019

\section{Úvod}

Cílem př́spěvku je prezentace výsledků výzkumu, jehož cílem bylo současné vnímání a postoje občanů k problematice chudoby v mikroregionu Karvinsko. Úvodní část př́íspěvku se zaměřuje na soudobou problematiku chudoby z hlediska subjektivní a relativní chudoby, její příčiny a důsledky. Představuje typy chudoby, které souvisejí s moderní společností a současnou životní úrovní občanů. Obsahem druhé části př́spěvku jsou výsledky výzkumu, který byl realizován a vyhodnocen v roce 2017. Cílem zkoumání bylo vnímání a hodnocení vlastní životní úrovně občanů mikroregionu Karvinsko a jejich postoje $\mathrm{k}$ sociálně demografickým skupinám, které jsou ohroženy chudobou a sociální exkluzí. Vzhledem k cíli výzkumu byl vybrán typ kvantitativního zkoumání, metodou dotazování, technikou dotazníku. V závěru příspěvku budou komparovány výsledky terénního zkoumání s vybranými teoretickými názory autorů odborných publikací.

Chudoba je široký problém, který ovlivňuje socializaci člověka což je v podstatě pozice jedince ve společnosti. Chudoba omezuje člověka ve všech oblastech života, zejména jeho sociální vztahy a tím způsobuje jeho izolaci od společnosti. Může se jednat o omezení kontaktu $\mathrm{s}$ přáteli, omezenou volbou vzdělání a s tím související možnosti a př́ležitosti na trhu práce (Večerník a Myslíková 2015). V další oblasti života může chudoba způsobovat omezené možností dovolené či komfort bydlení a s tím související vybavenost bydlení. Život v bídě taktéž utváří názory a postoje lidí a tím ovlivňuje společnost, zejména přes politické prostředí země prostřednictvím voleb (Žižková In: Krebs 2015). Podle Tomeše (2001) je vnímání chudoby v evropských podmínkách výsledkem působení křest’anského náboženství a také ideálu rovnosti, jenž pochází podle něj zejména $\mathrm{z}$ dob socialismu. 
Podle Žižkové (In: Krebs, 2015), existují tři hlavní kategorie př́ičin vzniku chudoby, jsou to: nízké př́ijmy ze zaměstnání, nezaměstnanost a propast ve vlastněném bohatství.

Tyto důvody vzniku chudoby se pojí s dvěma rozdílnými př́istupy $\mathrm{k}$ jejímu řešení. První př́istup předpokládá, že jednotlivci mají jen velmi malé možnosti, jak ovlivnit svou situaci. Příčinou je neexistence dostatku pracovních míst a vysoká míra nezaměstnanosti. Proto se očekává, že chudobu bude řešit a finančně mírnit stát. Druhý prrístup předpokládá, že za svou chudobu si může každý sám, nebot' není dostatečně pracovitý, dravý či adaptibilní. Je tedy na samotných chudých, aby řešili svou situaci, stát se na tomto řešení nijak nepodílí. (Krebs 2015). V prezentovaném výzkumu (viz druhá část př́spěvku) se vybraní respondenti vyjadřovali $\mathrm{k}$ úloze státu $\mathrm{v}$ prevenci a řešení chudoby. Jejich názory byly rozdílné, jelikož souvisely především $\mathrm{s}$ jejich sociálním statusem a vlastními zkušenostmi na trhu práce. To dokazuje, že by se měly být oba př́stupy vzájemně propojovat tak aby výsledný př́stup byl vyvážený.

Přes třicet milionů občanů Evropské unie žije na hranici chudoby. Hmotný nedostatek sužuje především Bulhary. Ve Švédsku naopak bída ohrožuje jen necelé procento populace. Česká republika je v žebříku se zhruba $4 \%$ na devátém místě (Tancerová 2018). Podle průzkumu z Eurostatu vyplývá, že asi 33000000 obyvatel Evropské unie trápí těžká materiální deprivace. Ohrožení chudobou jsou podle něj lidé, kteří si nemohou dovolit alespoň čtyři z devíti položek, jež jsou podle autorů nezbytné pro adekvátní životní úroveň. Patří mezi ně telefon, automobil, pračka, televize, teplo, včasné placení účtů, schopnost vypořádat se s nečekanými výdaji, týdenní dovolená mimo domov a pravidelná konzumace masa (či jeho vegetariánské obdoby). Mezi občany Evropské unie bylo v roce 2017 zmiňovaných lidí 6,7 $\%$, což je skoro o dva procentní body méně než v roce 2010. Jednotlivě si během roku nepohoršil žádný stát s výjimkou Dánska, kde se počet materiálně deprivovaných zvýšil o půl procenta (Tancerová 2018).

\section{Chudoba jako sociální problém}

V současné moderní společnosti se setkáváme s pojmy materiální deprivace, energetická chudoba, relativní a subjektivní chudoba. Souvisí s potřebami občanů a současnou životní úrovní, která je podmíněna ekonomickými, společenskými a politickými faktory. Zejména ekonomická prosperita a politická vůle státu může svým občanům poskytnout i vyšší stupeň životní úrovně a pozitivně ovládat základní životní standard (Buryová 2015). S tím souvisí i sociální politika, která prostřednictvím systému sociálního zabezpečení preventivně chrání občany před absolutní chudobou (minimální mzda, životní a existenční minimum apod.).

Přesná definice pojmu chudoba není dána. Je to zejména kvůli tomu, že pojem chudoba je víceznačný pojem. Chudoba je vnímána vždy individuálně, a tudíž ji každý jedinec vnímá na základě vlastního cítění. (Krebs 2015) Proto pojem chudoba není přesně vymezen a každý autor ji formuluje podle svého pohledu. Např́klad Žižková (In: Krebs 2015, s. 118) ji vymezuje jako „stav, který je důsledkem nerovného prŕstupu k rozdělovanému bohatství společnosti, k jejím materiálním zdrojům, kdy životní podmínky a uspokojení základních potřeb nejsou v potřebné míře zabezpečeny dostatečnými zdroji a kdy tyto př́ijmy nelze z nějakých objektivních prŕčin zvýšit a kdy občan nedisponuje ani jinými zdroji či majetkem, který by mu umožnil získat prostředky ve výši, která je společností uznána jako minimální“. Žít v chudobě tedy podle Žižkové (In: Krebs 2015, s. 118) znamená žít bez toho, co je společností uznáno jako nutné. Tím vzniká pocit materiální deprivace. 
Jiný pohled má Townsend, kterého cituje Mareš (1999, s. 111) jenž vymezil chudobu: „Jedinci, rodiny a skupiny mohou být označeni za chudé, jestliže jejich zdroje nejsou postačující pro zajištění druhu stravy, participace, životních podmínek a požadavků, které jsou obvyklé nebo jejichž dosažení je přinejmenším široce podněcováno a schvalováno ve společnosti, k níž náležejí. Jejich př́ijmy jsou natolik pod úrovní př́ijmů, kterými disponují v této společnosti průměrní jedinci či rodiny, že je to de facto vylučuje z životních standardů, zvyklostí a činností v ní obvyklých.“

\subsection{Subjektivní a objektivní dělení chudoby}

Subjektivní koncepce chudoby souvisí s tím, jak každý jedinec hodnotí svou situaci, s tím, jestli se daná osoba či domácnost cítí být chudobou ohrožena či nikoliv. Je tudíž založena na individuálním vnímání chudoby a závisí na různých faktorech. Častokrát je pocit chudoby založen na srovnání toho, co osoba či domácnost má a co by chtěla, nebo toho co si myslí, že si zaslouží, případně co opravdu potřebuje nebo co mají ostatní. Mnozí lidé mohou vnímat sami sebe jako chudé i když ve skutečnosti chudými nejsou (př́kladem by mohl být jedinec, který se cítí být chudý, protože si nemůže dovolit auto a musí jezdit městskou hromadnou dopravou). Či naopak se chudý člověk nemusí cítit chudý, i když jím je (např́íklad imigrant, který žije s nízkým prŕíjmem ve vyspělé zemi). Z výše uvedeného vyplývá, že subjektivní chudoba nemůže určovat oficiální meze chudoby, ale dokresluje problematiku chudoby z hlubšího hlediska. Logicky tedy subjektivní chudoba odhaluje větší výskyt chudoby než chudoba objektivní (Žižková In: Krebs 2015). Mareš (1999) uvádí, že dle výzkumů se individuální vnímání situace mění postupem života. Do období středního věku se lidé cítí zřídka ohroženi chudobou, ale přibližně od padesáti let se tento pocit zvyšuje.

\subsection{Absolutní a relativní dělení chudoby}

Absolutní koncepce je jednou z částí objektivní chudoby. Je spojena s příjmem, který dovolí osobě uhradit náklady, které jsou nutné $\mathrm{k}$ holému přežití. Tomuto přijmu, říkáme substituční minimum (ukázkou by mohli být obyvatelé Afriky, zejména Somálska, kde stále hrozí smrt hladem). Tato chudoba je důležitá zejména v rozvojových zemích, kde je stále dosti aktuální, ve vyspělých zemích se zpravidla nevyskytuje. Mareš (1999) je toho názoru, že rozmezí tohoto druhu chudoby se nemění se změnou životní úrovně společnosti. Podle Walshe, Stephense a Moora (2000) absolutní chudoba obsahuje poměrné aspekty. Jako prríklad uvádí domácnosti, které jsou bez elektrické energie, jako ty, které jsou ve stavu absolutní chudoby vůči těm domácnostem, které připojení k elektrické energii mají.

Relativní koncepce je druhou částí objektivní chudoby. Je založena na tom, že jedinec dokáže uspokojit své základní potřeby, které jsou $\mathrm{v}$ dané společnosti zcela běžné, přesto se cítí chmurně, nebot' nedokáže zajistit své potřeby v míře, které jsou pro tu, kterou společnost, zcela standardní (například dnes je zcela obvyklé mít doma notebook či osobní počítač a jedinec který jej nemá, se může cítit touto skutečností deprimován). Tento typ chudoby se projevuje nedostatkem předmětu s dlouhodobou výdrží, nedostatečným bytovým pohodlím, či př́ijmem, který vylučuje schopnost spořit. Mareš (1999) zdůrazňuje, že chudoba v jednotlivých zemích je měřena $v$ souvislosti $s$ kvalitou života $v$ těchto zemích. Relativní chudoba je založena na porovnání této kvality života u chudých a „nechudých“. Dle Walshe, Stephense a Moora (2000) relativní chudoba souvisí s předměty, které jsou důležité pro vnitřní pohodu jednotlivce. Př́kladem uvádí nákup oblečení, které tuto pohodu navozuje. Ti, kteří jsou nuceni nakupovat oblečení v takzvaném ,secondhandu“, tedy oblečení s použitým ošacením, jsou relativně chudí, vůči těm, kteři si mohou dovolit ošacení nové. 
Problematikou relativní chudoby se zabýval již v 18. století Adam Smith, který tvrdil, že chudoba je neschopnost si dovolit nejen komodity, které jsou nezbytně nutné pro podporu života, ale bez ohledu na to, jaký je obvyklý zvyk země. Jiní zahraniční autoři (Raphael 2009, Townsend 1979) vnímají relativní chudobu jako nejužitečnějším opatření pro zjištění míry chudoby v bohatých rozvinutých zemí. Walker a Smith (2001) spojují relativní chudobu s relativní deprivací, kde je př́činou nedostatek zdrojů na udržení stravy, životního stylu, aktivit a materiálních potřeb, na které jsou jednotlivci nebo skupina zvyklí a které jsou standardem ve společnosti, do které patří.

Definovat absolutní nebo relativní chudobu je problematické, protože př́ijem mírně nad nebo pod životní úrovní není podstatně odlišný; negativní účinky chudoby jsou spíše kontinuální než diskrétní a stejný nízký př́íjem ovlivňuje různé lidi různými způsoby. Proto byla zavedena metrika př́jmové nerovnosti nebo indexy chudoby. Ekonom Robert C. Allen (2009) se to snažil vyřešit prostřednictvím standardizovaných košů zboží, které jsou typické pro ty, které nakupují chudí lidé v různých zemích a v určitém historickém období.

\subsection{Energetická chudoba}

Energetická chudoba je pojem, který lze v EU slyšet stále častěji. Neexistuje pro něj jednotná definice. Obecně ale popisuje stav, kdy lidé nemají dostatek energie pro dostatečné vytápění nebo chlazení svých domácností, na vaření, osvětlení a využívání spotřebičů, nebo jsou pro ně náklady na tuto energii př́liš vysoké (Denková 2017).

Podle Evropské komise takovým stavem trpí v Unii více než 23 milionů domácností. Nejvíce jsou postiženy země na jihu Evropy - Řecko, Portugalsko nebo Bulharsko.

V České republice, podle Energetického regulačního úřadu (ERÚ), je ohroženo energetickou chudobou asi $20 \%$ domácností. Skutečně postiženo je už $6 \%$ Čechů. Česká republika si oproti unijnímu průměru (10 \%) vede lépe (Denková 2017).

\subsection{Chudoba optikou genderové rovnosti}

Statistiky z let 2014-2016 ukazují, že chudoba v Evropě, respektive v České republice, je silně feminizovaná. Na tuto problematiku upozorňuje nově vydaná studie Gender a energetika, kterou zpracoval Sociologický ústav ve spolupráci s německou politickou nadací Heinrich-Böll-Stiftung v roce 2016. Jak uvádí Marková Volejníčková a kol. (2016, s. 45): „Termín feminizace chudoby označuje celosvětový trend zvyšujícího se podílu a převahy chudoby mezi ženami ve srovnání s muži.“”

Jak autorky ve své studii (2016) uvádějí, žen, které jsou v Evropě ohroženy chudobou, bylo v roce 2014 více než mužů. Chudoba se konkrétně týkala 65 milionů žen a 57 milionu mužů. V České republice bylo ve stejném roce chudobou zasaženo 13,3 \% mužů a 16,3 \% žen. Příčiny chudoby u mužů a žen jsou často odlišné. Ženy se častěji dostávají do této situace v okamžiku, kdy zůstávají po rozchodu s partnerem samy s dětmi. Více se chudoba dotýká starších žen, samoživitelek, žen samostatně žijících, lesbických, bisexuálních a transgender žen, žen s postižením a žen $\mathrm{z}$ etnických minorit.

V České republice jsou ohroženy chudobou ženy v důchodovém věku. Je to dáno rozdílem mezi muži a ženami v sociálním zajištění ve stáŕí, které jsou způsobené mzdovými rozdíly mezi muži a ženami v průběhu života. Dalším faktorem je i neplacená práce a péče o děti, kterou častěji zajišt'ují ženy. V populaci nad 65 let je v důsledku toho míra ohrožení chudobou žen $(13,6 \%)$ oproti mužům $(6,9 \%)$ zhruba dvojnásob. 


\section{Výzkum v mikroregionu Karvinsko}

Ve druhé části príspěvku bude představen výzkum v mikroregionu Karvinsko. Cílem výzkumu je vnímání a klasifikace vlastní životní úrovně občanů v mikroregionu Karvinsko a postoje občanů k sociálně demografickým skupinám, které jsou ohroženy chudobou a sociální exkluzí. Pro výzkum bylo Karvinsko vybráno pro své ekonomické a demografické problémy, se kterými se již několik let potýká. První část bude věnována socio-demografické charakteristice, následující představí výsledky terénního výzkumu.

$\mathrm{V}$ rámci př́pravné fáze výzkumu byly vyhledávány podobné výzkumné aktivity v rámci EU a zejména v České republice s cílem porovnat výsledky zkoumání. Problematikou chudoby relativní chudoby a materiální deprivace v zemích EU se zabývá EUROSTAT a EUROBAROMETR. Z výsledků v roce 2017 vyplynulo, že Česká republika patř́ k nejméně ohroženým státům př́jjmovou a materiální chudobou $\mathrm{z}$ postkomunistických států $\mathrm{v}$ EU. Problematice výzkumů př́ijmové chudoby a materiální deprivace v České republice se věnoval Sirovátka (2011), který se ve své analýze zaměřil na pracující v ČR. Jahoda (2015) vydal podobnou analýzu, která se zaměřovala na seniory, podobně jako Horáková (2015), která se ve své analýze př́ijmové chudoby zaměřuje na děti a období krize z let 2008-2011.

Našim výzkumným cílem byly názory občanů na vlastní životní úroveň, a zdali se cítí být chudí (relativní chudoba), dílčími cíli byli názory občanů na intervenci státu v oblasti prevenci chudoby (existenční, životní minimum a minimální mzda) a názory na sociální exkluzi (skupiny ohrožených občanů, prŕčiny sociální exkluze). Na rozdíl od jiných dostupných výzkumů $\mathrm{v}$ této oblasti jsme se nezaměřovali na vybranou demografickou skupinu. Naopak, cílem zkoumaného souboru byly občané, rozdělení do demografických skupin a to tak, abychom získali názory od pracujících, nezaměstnaných, seniorů, studentů a osob samostatně výdělečně činných a jejich názory mohly komparovat. S takovým typem zkoumání jsme se dosud z dostupných pramenů nesetkali. Místo výzkumu bylo zvoleno záměrně. Mikroregion Karvinsko prošel mnohými hospodářskými a sociálně-demografickými změnami v posledních desetiletích a je jedním $\mathrm{z}$ regionů, kde je nejvyšší nezaměstnanost a počet stárnoucích obyvatel.

\subsection{Socio-demografická charakteristika mikroregionu}

Charakteristika mikroregionu Karvinsko je dána jeho územní polohou, ekonomickou a demografickou strukturou. Velkým problémem je vysoká nezaměstnanost a stárnutí obyvatel. V rámci karvinského okresu je Karviná městem s druhým největším počtem obyvatel za Havíŕovem, který měl ke konci roku 201772382 obyvatel.

V Karviné žilo podle údajů Českého statistického úruadu k 31.12. 201753522 osob, z toho 26 387 mužů a 27135 žen.

Nejpočetněji je zastoupena věková skupina 15-64 let, ale narůstá počet osob starších 65 let. Věkový průměr obyvatel města byl ke stejnému datu 43,8 let (Podrobněji Tabulka 1).

Tabulka 1: Počet a věk obyvatelstva ve městě Karviná k 31.12.2017

\begin{tabular}{|l|c|}
\hline Počet obyvatel & 53522 \\
\hline z toho muži & 26387 \\
\hline z toho ženy & 27135 \\
\hline z toho ve věku 0-14 let & 7238 \\
\hline z toho ve věku 15-64 let & 35050 \\
\hline z toho ve věku 65 a více let & 11234 \\
\hline Průměrný věk & 43,8 \\
\hline
\end{tabular}

Zdroj: Český statistický úřad, veřejná databáze 2018 
Podrobnou charakteristiku sociálních poměrů v Karviné nabízí výsledky sčítání lidu z roku 2011. Podle něj žilo k uvedenému období v Karviné 56897 obyvatel, z nichž většina (téměř 39000 osob, 68, 5 \%) náležela $\mathrm{k}$ věkové skupině 15-64 let. Podle rodinného stavu mírně převažovali ženatí/vdané nad svobodnými (22 675, resp. 22 026). Podle druhů ekonomické činnosti bylo v kategorii zaměstnaných evidováno 21046 obyvatel. Z nich nejpočetněji byly zastoupeny osoby zaměstnané v průmyslu (6 788 obyvatel, 32,2 \%). Podle nejvyššího ukončeného vzdělání byly nejpočetnější skupinou osoby se středoškolským vzděláním bez maturity, včetně vyučených (18 340, 32,2 \%). Druhou nejpočetnější skupinou byly osoby se základním vzděláním, včetně neukončeného (12 048, 21,2 \%), naproti tomu ukončené vysokoškolské vzdělání uvádělo 3349 osob (5,9\%). Podle státního občanství převažovaly v Karviné osoby, uvádějící př́íslušnost k ČR $(97,2 \%)$. Pestřejší byla národnostní struktura. Českou národnost uvádělo téměř $34000(59,4 \%), 3226$ obyvatel $(5,7 \%)$ se hlásilo k polské národnosti a dalších $3065(5,4 \%)$ ke slovenské. Téměř 13000 obyvatel města $(22,8 \%)$ národnost neuvedlo. Za místní specifika lze považovat uvádění moravské (1 $136 \mathrm{osob}, 2 \%$ ) a slezské národnosti (472 osob, $0,8 \%$ ). K romské národnosti se přihlásilo 84 osob $(0,1 \%)$. Většina obyvatel Karviné neuváděla prríslušnost $\mathrm{k}$ žádnému náboženství. Za věřící se při sčítání lidu označilo celkem 13630 osob (23,9\% obyvatel). Z toho 9117 osob (16\%) se hlásilo k některé církvi či náboženské společnosti. Mezi nimi jednoznačně převažovali věřící, kteří vyznávali katolictví (6 289 osob, 11,1 \%).

Typickým specifikem Karviné byl i v době uvedeného sčítání lidu populační pokles. Tato tendence demografického vývoje charakterizuje také situaci v celém Moravskoslezském kraji. Podle publikace Krajské správy Českého statistického úřadu (2016) je zde patrný pravidelný meziroční pokles počtu obyvatel od poloviny 90 . let. Výjimku z tohoto trendu představovala situace v letech 2007 a 2008. V letech 2010-2015 byl v rámci Moravskoslezského kraje zaznamenán nejvýraznější populační pokles v okrese Karviná - a to vlivem migrace i v důsledku přirozeného úbytku obyvatelstva. Okres Karviná měl také v rámci kraje obyvatele $\mathrm{s}$ nejvyšším průměrným věkem, který koncem roku 2015 činil 42,5 let (Krajská správa Českého statistického úradu, 2016). Populační pokles v Karviné potvrzují i data za rok 2017, kdy se ve městě narodilo 495 dětí, ale statistika zemřelých čítá 692 osob. Zápornou hodnotu vykazuje také př́růstek stěhováním, který činí mínus 694 osob (podrobněji viz Tabulka 2).

Tabulka 2: Pohyb obyvatel k 31. 12. 2017

\begin{tabular}{|l|l|}
\hline Živě narození & 495 \\
\hline Zemřelí & 692 \\
\hline Přistěhovalí & 756 \\
\hline Vystěhovalí & 1450 \\
\hline $\begin{array}{c}\text { Přírůstek (úbytek) } \\
\text { Přirozený }\end{array}$ \\
\hline Stěhováním & -197 \\
\hline Celkový & -694 \\
\hline
\end{tabular}

Zdroj: Český statistický úřrad, veřejná databáze 2018

Populační pokles $\mathrm{v}$ Karviné je patrný zvláště $\mathrm{v}$ dlouhodobém časovém srovnání. Podle databáze demografických údajů za obce ČR žilo na začátku 70. let 20. století v Karviné 76 075 obyvatel a jejich počet $\mathrm{v}$ následujících letech dále rostl. Maxima dosáhl v roce 1978, kdy se počet obyvatel ve městě zvýšil na 81693 . Od konce 70 . let se začala populace města opět postupně snižovat. K hlavním příčinám tehdejšího populačního poklesu patřilo oslabování státem podporované bytové výstavby, která se větší míře prresunula do blízkých měst (konkrétně do Havírova a Orlové). 
V 90. letech 20. století klesl pod 70 000. Setrvalý pokles pokračoval i v dalších letech a také v druhém desetiletí 21. století, na jehož začátku Karvinou obývalo už méně než 60000 občanů. Pokračující populační pokles je zapř́ičiněn řadou faktorů. Podle Poledníka (2014) na demografický vývoj působí především vliv migrace, směřující do vzdálenějších sídel i do okolních obcí. Výraznější vystěhovávání $\mathrm{z}$ města je především důsledkem dopadů ekonomické transformace na místní trh práce. Svou roli přitom hraje i působení negativních sociálních jevů a jejich vnímání.

\subsection{Analýza výsledků výzkumu}

Výzkum probíhal v roce 2017 od ledna do března. Byl zvolen typ kvantitativního výzkumu, metodou dotazování, technikou dotazníku. Důvodem zvolené metodiky výzkumu bylo oslovit široké spektrum občanů. Celkem bylo distribuováno 600 dotazníků. Návratnost byla poměrně vysoká, celkem 580 dotazníků. Na výzkumu se podílelo celkem 10 studentů Obchodně podnikatelské fakulty $\mathrm{v}$ Karviné z prezenčního i kombinovaného studia oborů Veřejná ekonomika a správa a Sociální management, dále firmy a neziskové organizace na Karvinsku, které nás kontaktovaly s respondenty z řad nezaměstnaných, pracujících a seniorů. Dotazníky byly distribuovány i ve zdravotnických zařízeních (se souhlasem vedení), kde jsme úspěšně mohli oslovit zejména seniory ale i ostatní sociální skupiny občanů. Největším problémem bylo získat dostatečný počet respondentů ze skupiny podnikatelů, kteří byli nejméně ochotni se výzkumu zúčastnit. Po opakovaných schůzkách a ve spolupráci s Magistrátem města Karviná a Havířov se nám to nakonec podařilo.

Dotazník obsahoval celkem 14 otázek. Otázky byly zaměřeny na osobnostní údaje respondentů, dále na jejich ekonomickou aktivitu (byla klíčová pro rozdělení do demografických skupin) a do jaké př́ijmové skupiny se zařazují (měsíční prŕijem). Následovaly otázky týkající se subjektivní pocitu chudoby či bohatství a názorů na dostatečnou výši existenčního, životního minima a minimální mzdy. V druhé části dotazníku se respondenti vyjadřovali k sociální exkluzi. Které skupiny občanů považují za rizikové a jaký je způsob řešení. V dotazníku byly využity jak otázky uzavřené, kde respondent volil jednu z možných odpovědí, tak i otázky otevřené, kde respondent vyjádřil svůj názor.

Dotazovaní byli rozděleni do pěti demografických skupin: studenti, nezaměstnaní, senioři, zaměstnaní a osoby samostatně výdělečně činné (OSVČ). Cílem stanovení těchto skupin bylo diferencovaně zpracovat a komparovat názory mladých studentů s lidmi středního a pozdního věku v plné zaměstnanosti, seniory, kteří pro nás hypoteticky představovali skupinu, která je ohrožena chudobou a sociální exkluzí podobně, jako skupina nezaměstnaných. V protikladu byla skupina osob samostatně výdělečně činných, kteři představovali skupinu hypoteticky bohatých lidí. Všechny demografické skupiny byly poměrně stejně početně i genderově ve výzkumu zastoupeny.

Distribuce dotazníků byla realizována na území města Karviné a přilehlých obcí. Dále část města Havířova a Orlové.

Z celkového počtu dotazovaných občanů bylo $57 \%$ žen a $43 \%$ mužů.

Věkové rozpětí respondentů činilo: do 25 let $-22 \%$, od 26 do 45 let $-34 \%$, od 45 do 65 let $26 \%$ a nad 66 let $-18 \%$.

Poměrné zastoupení respondentů z hlediska pohlaví a věku bylo pro výzkum důležité $\mathrm{z}$ důvodu plurality názorů na chudobu a vztah ke skupinám občanů, kteří jsou chudobou nejvíce ohroženi. 
Následovně byli respondenti rozděleni do př́jmových skupin. Necelá polovina oslovených studentů - $47 \%$ patří do příjmové skupiny pod 5000 Kč měsíčně. Do této prŕímové skupiny se řadí také $69 \%$ nezaměstnaných respondenti̊. Polovina oslovených starobních důchodců $53 \%$ má př́ijem v rozmezí 10 až 15 tisíc Kč měsíčně. Většina zaměstnaných se pohybuje v př́ijmovém rozmezí 15 až 25 tisíc Kč měsíčně. Více jak polovina OSVČ - 56 \% udává př́ijem vyšší než 30 tisíc Kč měsíčně (viz. Obrázek 1).

Obrázek 1: Př́ijmové skupiny respondentů (v \%)

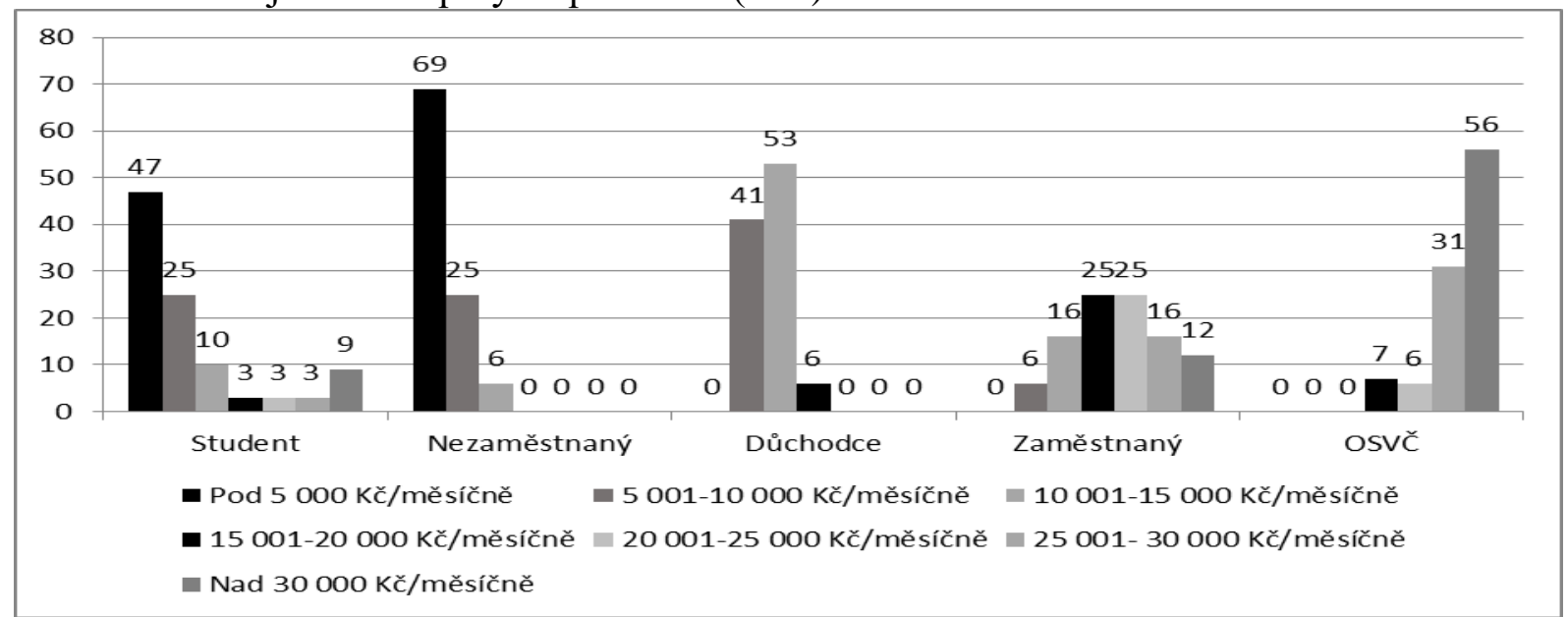

Zdroj: Vlastní výzkum 2017

V dotazníku se oslovení občané vyjadřovali k nástrojům sociální politiky v České republice, které mají zabránit vzniku chudoby. Jde o minimální mzdu, životní a existenční minimum.

Minimální mzda je nejnižší přípustná výše odměny za práci v pracovněprávním vztahu. Její základní právní úprava je stanovena zákoníkem práce (zákon č. 262/2006 Sb., ve znění pozdějších předpisů). V roce 2018 byla schválena minimální mzda ve výši 12200 Kč (Tröster a Koldinská et al., 2018). Jak ukazuje Obrázek 2, jsou všechny oslovené skupiny, kromě OSVČ pro zvýšení minimální mzdy. Respondenti OSVČ by ponechali výši minimální mzdy v současné podobě - $34 \%, 35 \%$ by minimální mzdu zvýšilo. Zajímavý je údaj - $22 \%$ oslovených OSVČ se o výši minimální mzdy nezajímá. Možná je to dáno tím, že většina oslovených OSVČ podniká ve službách, kde je znám obecný problém s financováním jak ze strany státu, tak i ze strany klientů služeb.

Obrázek 2: Názory respondentů na minimální mzdu (v \%)

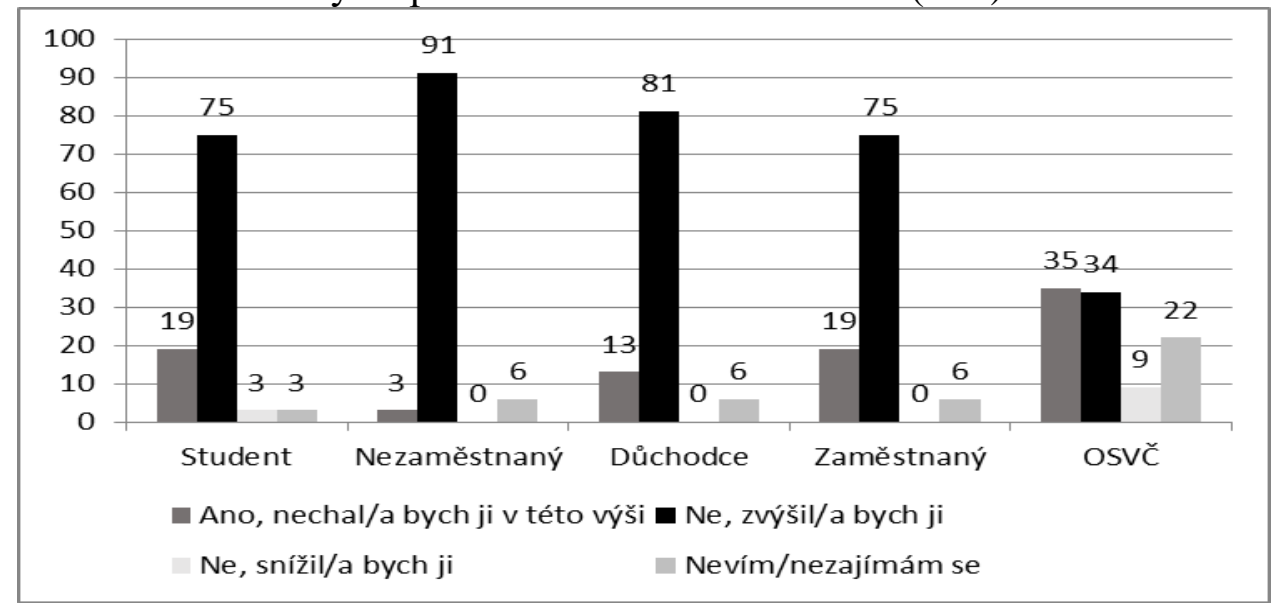

Zdroj: Vlastní výzkum 2017 
Následující Obrázek 3 představuje výsledky názorů oslovených občanů na výši existenčního minima. Životní a existenční minimum jsou důležité pojmy, které popisují takovou minimální výši př́ijmů, která je z pohledu naší společnosti minimálně přijatelná pro zajištění naší výživy a ostatních osobních potřeb-životní minimum, př́ípadně která je nutná k pouhému přežitíexistenční minimum (Turečková a Buryová 2017).

Kromě respondentů OSVČ jsou ostatní respondenti pro navýšení existenčního minima z více jak dvou třetin. Jako dostatečné ho vnímá $35 \%$ oslovených OSVČ, čtvrtina $-31 \%$ by byla pro jeho zvýšení a $25 \%$ se o existenční minimum nezajímá.

Obrázek 3: Názory respondentů na existenční minimum (v \%)

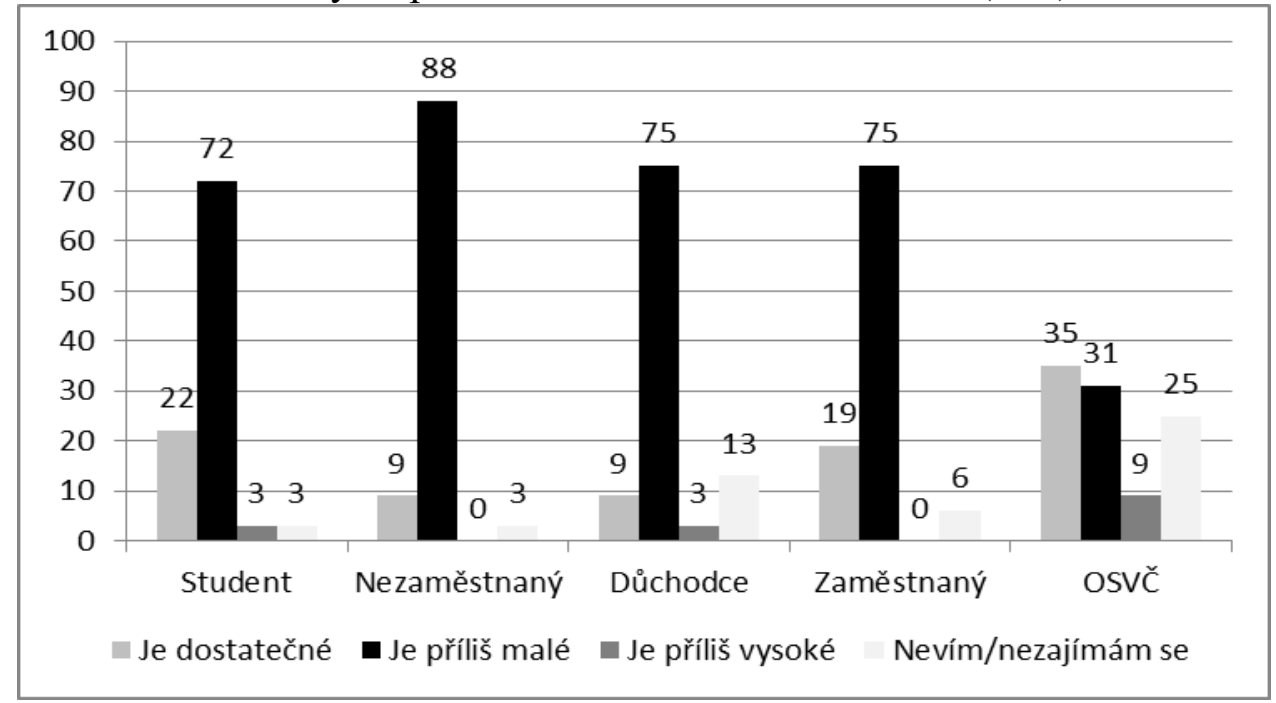

Zdroj: Vlastní výzkum 2017

Podobné názory měli respondenti i na výši životního minima. Opět více jak dvě třetiny oslovených skupin respondenti̊ byly pro jeho navýšení. Nejvíce byli pro navýšení nezaměstnaní $(97 \%)$ a studenti $(78 \%)$. Respondenti OSVČ vnímají současnou výši jako dostatečnou v počtu $44 \%$. Čtvrtina $-25 \%$ si myslí, že je třeba existenční minimum navýšit, $22 \%$ oslovených OSVČ to nezajímá.

V dalši části dotazníku se respondenti vyjadřovali k tomu, zdali se cítí být nejbohatší, bohatí, spíše bohatí, spíše chudí, chudí nebo nejchudší. Jednalo se o uzavřené otázky, kde respondenti volili jen jednu z možností. Tato otázka byla jednou z kličcových, která úzce souvisela s cílem výzkumu.

Většina studentů - $50 \%$ se hodnotí jako lepší střed žebříčku chudoby, tedy spíše bohatí. Oslovených $25 \%$ se ale cítí, jako spíše chudí, $6 \%$ oslovených studentů se cítí být nejbohatšími.

Naopak, většina nezaměstnaných - 56 \% se na žebříčku chudoby ohodnotila jako nejchudší a $19 \%$ se cítí být chudí, což se dalo předpokládat. Zajímavý je ale i údaj, kde se $16 \%$ nezaměstnaných cítí jako nejbohatší. Zde se dá předpokládat určitý stupeň subjektivity materiální existence a s ní související i materiální chudobu, která u $16 \%$ nezaměstnaných pravděpodobně není problém. Jinými slovy, nemají peníze, ale jsou materiálně zabezpečeni a nestrádají. Je možné, že jsou součástí bohaté rodiny nebo mají menší nároky na svou životní úroveň. 
Necelá polovina oslovených starobních důchodců (47\%) a většina zaměstnaných $(69 \%)$ se také hodnotí jako lepší střed, tedy spíše bohatí. U starobních důchodců je tento údaj celkem překvapivý. Hypoteticky jsme předpokládali, že se starobní důchodci budou vnímat jako skupina chudých a spíše chudých. Pokud sečteme procenta, která představují vnímání se na hranici chudoby, jde u oslovených důchodců asi o polovinu (53\%).

Polovina respondentů OSVČ - 50 \% se klasifikuje na žebříčku chudoby jako bohatí a $28 \%$ spíše bohatí, což jsme ve výzkumu předpokládali. Spíše chudí se cítí být $19 \%$ a $3 \%$ respondentů se vnímají jako chudí.

U respondenti̊ OSVČ ani u zaměstnaných se nikdo necítí být nejbohatší, přestože obě skupiny patří do dvou nejvyšších prríjmových skupin z dotazníku.

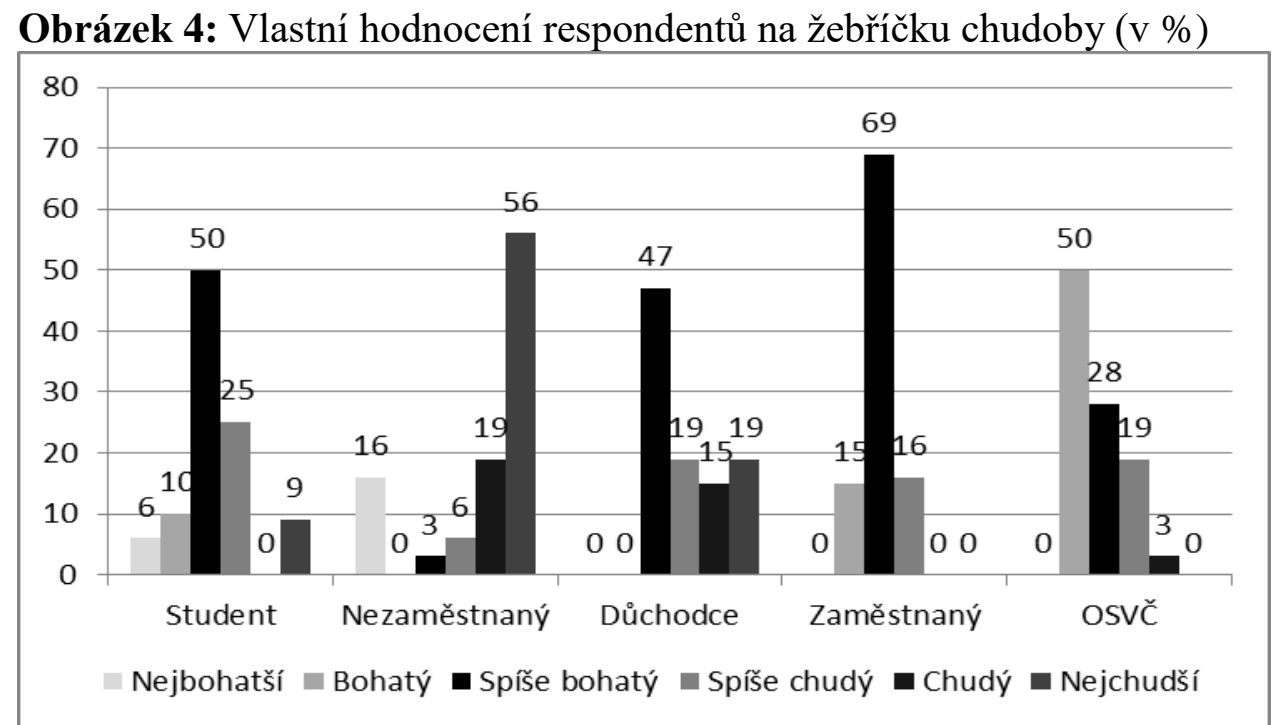

Zdroj: Vlastní výzkum 2017

V poslední části dotazníku vyjadřovali respondenti své názory na skupiny občanů v České republice (nezaměstnaní, zdravotně handicapovaní, matky samoživitelky, lidé přicházející z výkonu trestu, mladí lidé, kteří odcházejí z dětských domovů, senioři, lidé bez domova, cizinci a uprchlíci) které jsou ohroženy chudobou. Měli zvolit jednu či více možností a určit na stupnici její důležitost: 1- zřídka ohroženi chudobou, 5- vysoce ohroženi chudobou.

Pokud respondent u dané skupiny obyvatel ohrožených chudobou nechal prázdné místo, znamenalo to, že si nemyslí, že by daná skupina byla chudobou ohrožena.

Názory studentů:

Z celkového počtu oslovených studentů si $60 \%$ myslí, že nejvíce ohroženou skupinou jsou lidé bez domova. Nejméně ohroženi chudobou jsou pak cizinci a uprchlíci, o nichž si to myslí $31 \%$ respondentů. U oslovených studentů je zajímavý výsledek, který se vztahuje na skupinu občanů, která je středně ohrožená chudobou. Je procentuálně vyšší než u jiných skupin respondentů. Středně jsou chudobou ohroženi dle $50 \%$ oslovených studentů zejména matky samoživitelky, 38 \% studentů považuje za středně ohrožené také lidi, kteří přichází z výkonu trestu. 


\section{Názory nezaměstnaných:}

Podle $50 \%$ oslovených nezaměstnaných jsou nejvíce ohroženi chudobou lidé bez domova. Nejméně jsou chudobou dle nezaměstnaných ohroženi cizinci a uprchlíci, což si myslí 47 \% respondentů. Zajímavým výsledkem je, že polovina oslovených nezaměstnaných $(53 \%)$ si myslí, že senioři nejsou skupinou, která by byla ohrožena chudobou.

\section{Názory seniorů:}

Z celkového počtu respondentů si 38 \% oslovených seniorů myslí, že nejčastěji jsou ohroženi chudobou lidé bez domova a matky samoživitelky, jak se vyjádřilo $37 \%$ respondentů. Dále považuje $38 \%$ oslovených senioru za ohroženou skupinu i zdravotně handicapované. Zcela negativní postoj mají oslovení senioři k nezaměstnaným, $\mathrm{k}$ lidem, kteří přicházejí z výkonu trestu, $\mathrm{k}$ uprchlíkům a $\mathrm{k}$ cizincům.

\section{Názory zaměstnanců:}

Respondenti ze skupiny zaměstnaných považují za nejvíce ohroženou skupinu chudobou bezdomovce, konkrétně $66 \%$ zaměstnaných. Nejméně jsou chudobou ohroženi dle zaměstnaných cizinci a uprchlíci (19\%). Z celkového počtu si $44 \%$ zaměstnaných myslí, že chudobou jsou ohroženy matky samoživitelky, 37 \% vnímá jako uhrožené i zdravotně handicapované. Tak jako $\mathrm{v}$ předchozích skupinách respondentů se vyjadřují negativně $\mathrm{k}$ lidem, přicházejícím z výkonu trestu, $\mathrm{k}$ cizincům a uprchlíkům.

\section{Názory osob samostatně výdělečně činných:}

Respondenti ze skupiny OSVČ považují za nejohroženější skupinu chudobou matky samoživitelky - $84 \%$. Necelá polovina $(49 \%)$ uvedla jako ohrožené seniory. Více jak polovina oslovených respondentů OSVČ $(58 \%)$ vnímá zdravotně handicapované jako skupinu, ohroženou chudobou. Negativní postoj zaujímají k lidem bez domova - $53 \%$, k nezaměstnaným - $47 \%$ a k lidem, kteří přicházejí z výkonu trestu.

\section{Závěr}

Cílem příspěvku byla problematika současné chudoby a její vnímání veřejností. V teoretické části byly vybrány teoretické názory autorů odborných publikací, kteří definují pojmy subjektivní, relativní a absolutní chudoby. Shodují se v tom, že jde o problém, který souvisí se současnou životní úrovní moderní společnosti a je podmíněn ekonomickou vyspělostí daného státu (Žižková, Krebs a Tomeš). Jsou zde i názory (viz. Mareš, Townsend, Raphael), že rozmezí absolutní a relativní chudoby se nemění se změnou životní úrovně společnosti. Někteří odborníci i z řad ekonomie se snaží o metriku chudoby prostřednictvím spotřebních košů, které nakupují chudí a bohatí (Allen) Podle jiných autorů (Danková a Marková Volejníčková) je vnímání chudoby spojeno s materiální vybaveností, s př́ístupem k energií i $\mathrm{s}$ genderovou problematikou.

Vyvstávají tedy i otázky: Jak vnímají v současné době občané svou životní úroveň? Podle finančních př́ijmů? Podle materiálního vybavení? Jak se cítí být chudí nebo bohatí občané, kteří podle odborníků patři mezi skupiny ohrožené chudobou? Jak vnímá veřejnost tyto skupiny? Odpovědi měl částečně přinést výzkum v mikroregionu Karvinsko, který představuje území s rostoucí nezaměstnaností, s problémem stárnoucí populace a vysokou migrací obyvatel.

Výsledky výzkumu z velké části potvrzují teoretické názory uvedených odborníků. Současně jsou i z části překvapením. Výsledek, kde se mezi nejbohatší řadí $16 \%$ nezaměstnaných, kteří

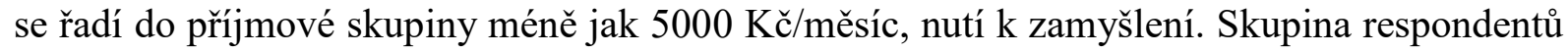


OSVČ, kteří mají příjmy vyšší jak 30 000/Kč/měsíc se nejbohatší být necítí. Dále překvapil i výsledek u skupiny respondentů z řad seniorů, kteři se $\mathrm{z}$ větší poloviny cítí být bohatými. Přitom jde o lidi v seniorském věku, kteří jsou obecně bráni jako potencionálně chudí. Takže které další faktory ovlivňují subjektivní pocity chudoby a bohatství? Můžeme dedukovat, že jde o životní pohodu, snížené nároky na materiální vybavenost, energii, životní styl a další. Jistě to jsou další podněty pro rozšířený výzkum v této oblasti.

Také názory na rizikové skupiny, které jsou ohroženy chudobou, jsou hodně subjektivní. Většina oslovených volila jako nejrizikovější skupinu lidi bez domova, což se dalo hypoteticky předpokládat. Skupina respondentů OSVČ považuje za ohrožené chudobou matky samoživitelky a zdravotně handicapované. Nezaměstnané a lidi bez domova zcela neguje. Výsledky výzkumu ukázaly současně na negativní postoj respondentů k cizincům a uprchlíkům, kteří chudobou podle nich ohroženi nejsou. Podobný názor mají i k lidem, kteří přicházejí z výkonu trestu. V této části výzkumu je zcela jasné, že výsledky jsou ovlivněné zkušenostmi respondentů a proto je nelze paušalizovat. Snad jen postoj k cizincům a uprchlíkům mají všichni oslovení respondenti negativní. Je to dáno současným problémem migrace v Evropě a souvisí s nebezpečím terorismu, kterému v současnosti Evropa čelí.

Výzkum přinesl odpovědi na výzkumné otázky, současně ale vyvolává otázky nové. Jistě bude zajímavé pokračovat ve výzkumu $\mathrm{v}$ dalších regionech v rámci České republiky a komparovat výsledky mezi sebou.

\section{Literatura}

[1] ALLEN, R., 2009. The British Industrial Revolution in Global Perspective. Cambridge University Press. ISBN 978-0-521-68785-0.

[2] BURYOVÁ, I., 2015. The importance of communit research for designing social services. In: Znalosti pro tržní praxi 2015 - Ženy podnikatelky v minulosti a současnosti. Olomouc: Societas Scientiarum Olomucensis II. ISBN 978-80-87533-12-3.

[3] ČSÚ, 2018. Veřejná databáze - profil území. [online]. [2018-08-03]. Dostupné z https://vdb.czso.cz/vdbvo2/faces/cs/index.jsf?page=profiluzemi\&uzemiprofil $=31548 \& u=$ VUZEMI 43 _598917\#.

[4] DENKOVÁ, A., 2017. EU řeši energetickou chudobu. ČR se vede dobře, situaci nizkopríjmových domácností by ale mohla zlepšit. EUROACTIV [online]. [2018-08-08]. Dostupné z: https://euractiv.cz/section/cr-v-evropske-unii/news/eu-resi-energetickouchudobu-cr-se-vede-dobre-situaci-nizkoprijmovych-domacnosti-by-ale-mohla-zlepsit/.

[5] HORÁKOVÁ, M. a kol., 2013. Př́jmová chudoba a materiální deprivace v České republice podle indikátorů EU - vývoj v di̊sledku krize, fiskální konsolidace a sociální reformy. Praha: VÚPSV, v.v.i. ISBN 978-80-7416-129-2.

[6] JAHODA, R. a kol., 2015. Př́jmová chudoba a materiální deprivace seniori̊: subjektivní a objektivní pohledy. Praha: VÚPSV, v.v.i. ISBN 978-80-7416-215-2.

[7] KS, ČSÚ v Ostravě. Základní tendence demografického, sociálního a ekonomického vývoje Moravskoslezského kraje. [online]. [2018-03-30]. Dostupné z https://www.czso.cz/documents/10180/32501119/33013416.pdf/848d2f2f-2b92-4d6698f9-79d78ef5fd6c?version=1.2. 
[8] KREBS, V. a kol., 2015. Sociální politika. Praha: Wolters Kluwer. ISBN 978-80-7478$921-2$

[9] MAREŠ, P., 1999. Sociologie nerovnosti a chudoby. Praha: Sociologické nakladatelství. ISBN 80-85850-61-3.

[10] MARKOVÁ VOLEJNÍČKOVÁ, R. a kol., 2016. Gender a energetika. Praha: Sociologický ústav AV ČR, v.v.i., a Heinrich-Böll-Stiftung. ISBN 978-80-7330-297-9.

[11] POLEDNÍK, M., 2014. Aktualizace socioekonomických údajů v rámci rozboru udržitelného rozvoje území Karviná 2014. [online] [2018-03-30]. Dostupné z

http://uap.karvina.cz/_dokumentace/UAP_Vykresy/2014/Karvina_UAP_sociodemo_201 4.pdf.

[12] SIROVÁTKA, T. a kol., 2011. Rizika př́jmové chudoby a materiální deprivace v České republice : (celková situace a vybrané aspekty na datech SILC). Praha: VÚPSV, v.v.i. ISBN 978-80-7416-092-9.

[13] RAPHAEL, D., 2009. Poverty, Human Development, and Health in Canada: Research, Practice, and Advocacy Dilemmas. Canadian Journal of Nursing Research, 41/2, p. 7-18. ISSN 0844-5621

[14] TANCEROVÁ, T., Třicet milionů Evropanů žije na hranici chudoby, Čechy nedostatek netrápí. iDNES.cz/EKONOMIKA [online]. [2018-04-04]. Dostupné z: https://ekonomika.idnes.cz/chudoba-evropa-evropska-unie-eu-statistika-pruzkumeurostat-cesko-bulharsko-svedsko-g4rleko_euro.aspx?c=A180424_171027_eko_euro_tanc.

[15] TOMEŠ, I., 2001. Sociální politika: teorie a mezinárodní zkušenost. Praha: Socioklub. ISBN 80-86484-00-9.

[16] TOWNSEND, P., 1979. Poverty in the United Kingdom: A Survey of Household Resources and Standards of Living. University of California Press. p. 565. ISBN 9780520039766.

[17] TUREČKOVÁ, K. and I. BURYOVÁ, 2016. Economic Policy in context of income inequality gap: Case study of Czech Republic in 2005-2015. In: Proceedings of 14th International Scientific Conference Economic Policy in the European Union Member Countries. SU OPF Karviná, pp. 777-785. ISBN 978-80-7510-210-2.

[18] TRÖSTER, P., K. KOLDINSKÁ et al., 2018. Právo sociálního zabezpečení. Praha: C. H. Beck. ISBN 978-80-7400-692-0.

[19] WALKER, L. and J. SMITH, 2001. Relative Deprivation: Specification, Development, and Integration, Cambridge University Press, ISBN 0-521-80132-X.

[20] WALSH, M., P. STEPHENS and S. MOORE, 2000. Social policy \& welfare. Cheltenham: Stanley Thornes. ISBN 0-7487-4591-2.

[21] ŽIŽKOVÁ, J., 2015. Chudoba a problém chudoby v české společnosti. In: V. KREBS, eds. Sociální politika. Praha: Wolters Kluwer, s. 115-118. ISBN 978-80-7478-921-2. 